\title{
Household Accounting of Students for Siam Technology College in Bangkok
}

\author{
Sunisa Pimmanat
}

\begin{abstract}
This research aims to study 1) the state of accounting of the students of accounting faculty. Siam University College of Technology 2) Attitudes of Accounting Students Technology Siam University 3) Problems and Obstacles in Accounting of Households of Accountancy Students Technology Siam University

The instrument used to collect data was a questionnaire used for data analysis: frequency, percentage, mean, minimum, maximum, and deviation. Ben Standard

The research found that Student Accountant Technology Siam University Most have experience in household accounting. Ask the students to join the project. And have been trained in household accounting. Found that student accountant Technology Siam University Mostly understand the principles of household accounting and can be implemented. This may be because the content of household accounting is not too poor. And students are trained in household accounting and can be put into practice. This may be because the content of household accounting is not too poor and students are trained in household accountancy from the college.

Students have a strong consensus that household accounting is essential. It makes more money. When to recognize the various expenses. It will make their financial status whether it is balanced or not. And when you have a lot of income, but less money, it will save the remaining money to keep their savings. The details of their income each month. Recordings Into the household book. And also see that household accounting makes a careful and not spent extravagance. Cut off unnecessary expenses and extravagant items. In addition, the students strongly agreed that household accounting can make them suited to sufficiency economy. I know how to spend money, economize and have a family financial planning. Make people in the household have a simple life on the basis of sufficiency, which will lead to true happiness in the future.
\end{abstract}

Keywords - Household Accounting, Siam Technology College .

\section{INTRODUCTION}

In the present situation most students do not pay attention to their financial management. Do not know how much each month each month. What are the costs? And spend unpromisingly. Do not keep it consistently. The reason for over-spending is not balanced with income. And not to be able to plan the future.

Household account It does not mean accounting or recording daily income only. But may mean Recording of other aspects of life; In the family with For example, a property

Sunisa Pimmanat, Faculty of Accounting Siam Technology College, 46 Jarunsanitwong10 rd., Thapra branch, Bangkok-yai district, Bangkok 10600 Thailand account, a plant, a tree, a house in a community, an account of knowledge, a thought. Community Account Youth Account Wisdom, etc. means that things or stories. In life, you can take notes. You think that. If we do well, it will happen to us, the family, the community, the country, the more we, the family, the community, the country will be the people to learn. Learning family Learning community And country learning Learning is the source of wisdom. Wisdom is the source of all human, physical, social, spiritual and spiritual growth.

So this study. The researcher wanted to study the condition of bookkeeping, attitudes, problems and obstacles of Siamese College of Technology students. To make a household account To link to student savings. This is a guide to accounting for students. And can bring knowledge. Go to the account each day. This will make the students see the difficulty in earning and the burden of parenting that will benefit students and parents in terms of spending.

\section{RESEARCH OBJECTIVES}

1. To study the condition of household accounting of students in Siam Technology College. Bangkok

2. To study the attitudes of students in Siamese College of Technology. To make a household account. Bangkok

3. To study the problems and obstacles in household accounting of students in Siam Technology College, Bangkokon.

Sample Research tools Data collection And analysis of data as follows:

\section{A. Population and sample}

Population:

The research population was 400 SIiam Technology College students.

Sample

The samples used in this study were 100 students in year 1 to year 4

\section{B. Research tools}

Tools

The research tool was a questionnaire with closed-end questions and open-ended questions. The questionnaire was divided into 4 parts.

Chapter 1 Information on the personal characteristics of students, household accountants, including gender, age, household members Study of sample students. Household income And the most influential source for household accounting. There are 7 questions 
Chapter 2 Information on household accountancy conditions, including bookkeeping experience, before the accounting period. Accounting office Get support from the accounting department. Consistency in accounting Receive account books from the school, receive instructions on accounting, receive accounting instruction from the agency. Understand and apply the knowledge gained in household accounting after training. And the household recorder There are 10 questions in the questionnaire (the questions in Part 2 are based on the questionnaire in Kan Van Rawan 2007).

Chapter 3 Information on attitude of Siamese College of Technology students on household accounting. There are 12 questions in the questionnaire (the questions in this section are based on the questionnaire in Kanan Rawe 2007).

Chapter 4 Information on barriers and suggestions for household accounts. In terms of problems and obstacles in household accounting. Contains 7 questions, giving students the opportunity to discuss each issue as a barrier to household accountability. There are 5 levels of problem gauge. Interpretation of problems and obstacles of Siamese College of Technology students. To make a household account Take a mean weight loss approach. Compared to the criteria.

The questions about the suggestions of the students of Siam Technology College. To make a household account Open-ended questions.

\section{Questionnaire}

\section{Validity}

By the completed questionnaire. Consult the Advisory Board to verify the content. And make complete edits.

\section{Reliability}

The researcher conducted the questionnaire, which was reviewed and corrected according to the recommendations of the Advisory Board. Interview with Siam University Technology students In Bangkok, 400 students were interviewed in Part 3. To make a household account Statistical analysis to find the value. Using Microsoft Excel

\section{DATA COLLECTION}

In the data collection process. There are 2 steps: is Primary data and Secondary data.

\section{DATA ANALYSIS}

Data analysis by computer. Microsoft Excel. Statistics used in this research are Percentage, Mean and Standard deviation.

\section{THE ANALYSIS OF DATA}

Part 1 Analysis of Personal Data of Household Accountants

The study of individual characteristics of household accountants, including sex, age, household members Educational level of the sample students. Household income And information sources that influence household accountancy. Can be explained as follows.Sex Sample sex is $70 \%$ female. Age $75.0 \%$ were aged $17-18$ years and $25.0 \%$ were in the $19-20$ years.Number of household members The sample consisted of
45.0 percent of the household members, 28.0 percent of the household members, and 17.50 percent of the household members. There were two members in the household, 7.5 percent in the household and 2.0 percent in the household. 5 people or more.

\section{STUdY OF THE SAMPLE STUDENTS}

The samples were 43.75 percent at the 1-year level, 28.75 percent in the third year, and 27.50 percent in the sample group. Study in year 2 Family income $41.25 \%$ had a family income per year. \$ $150,001-200,00036.0 \%$ had family income per year in the range of 100,001 - 150,000 baht. Students had 12.50\%, had family income per year of less than 100,000 baht and $10.25 \%$. Earn more than 200,001 baht Family debt was 52.0\%, no debt and $48.0 \%$ debt.

\section{THE MOST INFLUENTIAL SOURCE FOR HOUSEHOLD ACCOUNTING}

The most influential source for household accounting was $84.25 \%, 33.0 \%$ were television and $7.50 \%$ were internet.

Part 2 Results Analysis of Household Accountancy

The study of the preparation. Household account of sample students. Experience in household

accounting. Time to make a household account Place in Household Accounting Supporting agencies in household accounting. The consistency of household accounting. Receiving Household Accounts Get advice on household accountancy. Understanding of household accounting after training. And letting others keep a record of the household. It was found that 90.5 percent of the sample had previous household accounting experience, 9.5 percent had no previous household accounting experience, 56.5 percent used household accounting hours, 34.0 percent used the morning session. Household accounting $77.0 \%$ of students $23.0 \%$ used home as a place for household accounting. Students are supported by the school. 80.0 percent of household accounts are recorded daily, 15.0 percent of household accounts are recorded, household accounts are once a week, 8.75 percent are household accounts. Weekly / monthly 6.25\% Household account 3 times / week All sample students receive household booklets from educational institutions. Get advice on household accountancy from the school. 92.0 percent of households were educated in the household accounting system. They were able to understand and apply it to 8.0 percent. The household record holder found that 100 percent of the samples were self-reporters.

The study of students 'attitudes toward household accounting was divided into 12 issues, which found that the students' attitudes were at the highly agreeable level. Students are required to make a household account. Household accounting makes more savings. Difficulties in household accounting make it impossible to make a household account. Household accounting makes it possible to plan more financially. Receiving advice from the school regularly will make you want to make more household accounts. To receive training from the 
school. Understand household accounting and implement it. Household accounting makes details. Income - Expenses of each month. Household accounting leads to life and well-being. Household accounting makes it possible to plan extra income / reduce unnecessary expenses.

\section{PROBLEM TO HOUSEHOLD ACCOUNTING}

A study of student Problem to household accounting. The sample students had problems in various aspects. The problem is divided into seven issues: (1) Household accountants lack experience in household accountancy. (2) Lack of public and private resources to further study household accountancy. (3) Lack of knowledge on household account bookkeeping. (4) Household accounting is difficult and time consuming. (5) Lack of assistance. (6) have a very responsible mission. (7) lack of facilities to record household accounts; Overall, it was found that. Most of the sample students had the lowest level of barriers to accounting Household.

\section{REFERENCES}

[1] Pinthong Suwansayanon (2005: 25) Studying the Concept of Fundamental Values of Savings and Savings In the third year of high school students in Bangkok, the values were at the desired level. Female students have higher savings and savings than men.

[2] Pratipon Nimphorn (2004: Abstract) Study on Factors Affecting Savings of Students in the Third Grade. The samples were Grade 1 - 3 students at Nawaminthrachinuth Subdistrict, Narathiwat School, Thawi Watthana District, Bangkok Metropolis. 320 students. The results showed that the factors that had a positive relationship with the economy of the third grade students were female.

[3] Gwynn Wong, Ph.D., Ph.D. (2003): A study of factors affecting saving behavior and savings of students in Rajamangala Institute of Technology. The commercial college of Phranakhon. Discipline The predicted saving behavior was 1.1 percent. 